\title{
Enhancement of $\alpha$-Glucosidase Production by Saccharomyces cerevisiae C8-5 and Candida tropicalis C0-7, Two Yeast Strains Isolated from Tchapalo, a Traditional Sorghum Beer of Côte d'Ivoire
}

\author{
Yapi Yapi Eric*, W.A.M. Alloue-Boraud, Coulibaly W. Hermann and \\ Djè Koffi Marcellin
}

\begin{abstract}
Biotechnology and Food Microbiology Laboratory, Department of Food Science and Technology, University of Nangui Abrogoua, Abidjan, 02 BP 801, Côte d'Ivoire
\end{abstract}

*Corresponding author

A B S T R A C T

Keywords

Saccharomyces cerevisiae

C8-5, Candida tropicalis

C0-7, $\alpha$-glucosidase, corn

starch, millet starch

Article Info

Accepted:

24 October 2018

Available Online:

10 December 2018
The hydrolase enzymes using in industrial processes have always given particular interest because of their non-toxic and protective nature. In the present study, various physicochemical parameters for $\alpha$-glucosidase production from strains of Saccharomyces cerevisiae C8-5 and Candida tropicalis $\mathrm{C} 0-7$ were optimized by using a starches of some agricultural products of Côte d'Ivoire. It was found that $S$. cerevisiae $\mathrm{C} 8-5$ and $C$. tropicalis $\mathrm{C} 0-7$ produced maximum $\alpha$-glucosidase after 48 hours of fermentation at $37{ }^{\circ} \mathrm{C}$, pH 7 and without agitation speed (0 rpm) using corn starch and millet starch $(1 \%)$. The more important $\alpha$-glucosidase activity were obtained with $S$. cerevisiae C8-5 by using $1 \%$ of corn starch $(15.96 \mathrm{U} / \mathrm{ml})$. It is conclued that corn and millet starches could be used in enzyme production, particulary the production of $\alpha$-glucosidase.

\section{Introduction}

Fermentation remains one of the old technologies used for food production and preservation (Holzapfel, 2002). In Africa, several fermented foods make a significant contribution to people's nutrition. Traditional beverages in particular, sorghum beer (Tchapalo) are experiencing considerable growth among the various populations in Côte d'Ivoire. However this beer is the result of an uncontrolled fermentation process, which contributes of the variability of its organoleptic properties from one producer to another (Alloue-Boraud et al., 2014). In order to contribute to the production of stable and healthy beers with constant organoleptic characteristics, several controlled fermentation trials have been carried out with selected starters of lactic bacteria and / or yeasts. Thus, the traditional Dolo beers (Burkina-Faso) and Burukutu (Nigeria) were produced from starters composed of Lactobacillus fermentum and Saccharomyces cerevisiae (Glover et al., 2009; Adewara et al., 2013). In Côte d'Ivoire, the study of N'guessan et al., (2011) selected a starter (S. cerevisiae $+C$. tropicalis) for the production of Tchapalo. During the fermentation process, starter strains produce several metabolites such as organic acids, 
alcohols, volatile compounds and enzymes that improve the final quality of the product. The use of yeast for enzyme production has several advantages, such as moderate temperature for microbial growth, high metabolic diversity and rapid cell growth, and is more energy efficient. This results in shorter fermentation cycles and easy adaptation of microorganisms to different growing conditions (Oliveira et al., 2015). Production of microbial enzymes is a necessary event in the industrial sectors, due to the high and superior performances of enzymes from different microbes, which work well under a wide range of varied physical and chemical conditions (Rajendra et al., 2016).

Enzyme mediated processes are rapidly gaining interest because of reduced process time, intake of low energy input, cost effective, nontoxic and eco-friendly characteristics (Li et al., 2012; Choi et al., 2015). Among the enzymes produced, amylolytic enzymes are contributed to the degradation of starch. These enzymes account for $25 \%$ to $33 \%$ of international market of marketed enzymes and are used in many industrial processes that require partial or total hydrolysis of starch (Özdemir et al., 2014).

Amylolytic enzymes are extensively used in biotechnology and have important applications in both the food and the pharmaceutical industries (Marin et al., 2006). Among the amylolitic enzymes, $\alpha$-glucosidase plays an important role in the process of metabolizing starch. Indeed $\alpha$-glucosidase is the final enzyme involved in the metabolism of starch to glucose, and is used with $\alpha$-amylase for the saccharification of starch (Gupta et Gautam, 1993). $\quad \alpha$-glucosidases $\quad(\alpha$-D-glucoside glucohydrolase; EC 3.2.1.20) hydrolyse the $\alpha$ glycosidic linkages from the non-reducing end of oligosaccharides and polysaccharides with the release of $\alpha$-glucose (Marin et al., 2006). This enzyme is used in food industry for the production of high-quality sugar syrups and confectionary, and it is employed to improve the texture of baked products (Muhammad et al., 2016).

Further, microbial enzymes are used in the treatment of health disorders associated with deficiency of human enzymes caused by genetic problems. $\alpha$-glucosidase can hydrolyze polysaccharide into glucose at terminal nonreducing $\alpha-1-4$-glycosidic linkage in small intestine, where the enzyme is located. The product from $\alpha$-glucosidase is monosaccharide such as glucose, which is absorbed into intestine wall. Thus, the inhibition of $\alpha$ glucosidase can, as well, control diabetes by delaying carbohydrate degradation and glucose absorption (Watcharachaisoponsiri et al., 2016). However, the cost of enzyme production is a major limitation for it's commercialization and it's mainly depends on the physico-chemical fermentation conditions (Nascimento and Martins, 2004).

In order to ensure the expansion of the enzyme production industry, it's essential to produce enzymes at a lower cost. Culture media are essential in the process of producing enzymes, the use of a less expensive culture medium and stimulating the production of enzymes would significantly lower the cost of production. Indeed, according to GarciaMartinez et al., (2010), culture media represent 30 to $40 \%$ of the total cost of enzyme production. The choice of an appropriate production medium is therefore essential for microorganisms, both for their growth and obtaining enzymes (Bouatenin et al., 2016). In order to reduce the cost of enzyme production, alternative culture media have been developed. Thus the use of agroindustrial residue losses for enzyme production can become economically important in the application of these biocatalysts on a large scale (Oliveira et al., 2015). It's in this context that several carbon 
sources such as banana peels, sorghum grains obtained during the production of $O g i$ in Nigeria and millet have been used in fermentation processes as substrates for enzyme production (Abu et al., 2005, Maktouf, 2013, Oliveira et al., 2015). Côte d'Ivoire has a variety of agricultural products potentially rich in starch among which are distinguished cereals (maize, millet, sorghum...), tubers (cassava, yam) and others. These products are for the most part used in human, animal or industrial food and their starches have never been valued in enzymes production. These starches could be used as a source of carbon for enzyme production and thus to constitute a substitute of synthetic starch whose accessibility remains difficult because of the relatively high price.

Exploration of $\alpha$-glucosidase from yeast source and cost-effective production strategy are indispensable factors in order to meet the escalating demand at commercial level.

The current study was to investigate the enzymatic potentialities of Saccharomyces cerevisiae $\mathrm{C} 8-5$ and Candida tropicalis $\mathrm{C} 0-7$ particularly, $\alpha$-glucosidase production for using corn starch and millet starch. Various physical and chemical parameters of growth medium were optimized to attain the maximum production yield of $\alpha$-glucosidase under submerged fermentation technique.

\section{Materials and Methods}

\section{Yeast strains and culture conditions}

Yeast species of $C$. tropicalis and S. cerevisiae used as starters in this study were belonged to the culture collection of the Food Technology Department (University of Nangui Abrogoua). They were isolated from traditional sorghum beer from the district of Abidjan (Southern Côte d'Ivoire). They were identified by PCRRFLP of the ITS region and sequencing of
D1/D2 domains of the 26S rRNA gene (N'guessan et al., 2011). Before their growth on solid state medium, yeasts were cultivated on 868 medium with chloramphenicol at 30 ${ }^{\circ} \mathrm{C}$ for $24 \mathrm{~h}$. This medium contained (w/v): glucose monohydrate $2 \%$, yeast extract (Organotechnie, France) $1 \%$, peptone casein (Organotechnie, France) $1 \%$ and agar (Merck, Germany) $1.5 \%$.

\section{Inoculum preparation}

A pure colony (24 hours) of each microorganism was inoculated in Erlenmeyer of $250 \mathrm{ml}$ containing $50 \mathrm{ml}$ of medium 863 (glucose $20 \mathrm{~g} / \mathrm{l}$, yeast extract $10 \mathrm{~g} / \mathrm{l}$, pepton 10 $\mathrm{g} / \mathrm{l}$ and chloramphenicol $0.5 \mathrm{~g} / \mathrm{l}$ ). These medium were incubated during 12 hours at $28^{\circ} \mathrm{C}$ (Bataiche, 2014).

\section{$\alpha$-glucosidase production}

The $\alpha$-glucosidase production medium is composed per liter of $1 \%$ peptone, $1 \%$ corn starch or millet starch, $0.5 \%$ yeast extract,

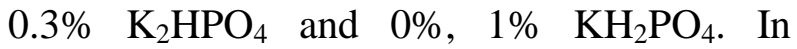
Erlenmeyer of $250 \mathrm{ml}$ containing $54 \mathrm{ml}$ of liquid fermentation medium constituted were inoculated with $6 \mathrm{ml}$ of inoculum. For cocultures, inoculum volume was set out again according the ratios between the microorganisms.

For each starch source, four fermentation media were constituted as follows: (1) individual pure fermentation medium with $C$. tropicalis and $S$. cerevisiae; (2) mixed fermentation media of both yeast strains, respectively, in ratios of 2:1 and 1:1 (cell/cell). These media were incubated at $30^{\circ} \mathrm{C}$ in orbital shaker (shaking incubator) set in $150 \mathrm{rpm}$ during 96 hours. At 0 h, 24 h, 48 h, 72 h and $96 \mathrm{~h}$, samples of $8 \mathrm{ml}$ were collected for $\alpha$ glucosidaseactivity and $\mathrm{pH}$ assay. The samples were centrifuged at $5000 \mathrm{rpm}$ at $4^{\circ} \mathrm{C}$ for 20 mn. The supernatants were collected and $\alpha$ - 
glucosidase assay was carried out using pNitrophenol - $\alpha$-D- glucopyranoside (p-NPG) method.

\section{$\alpha$-glucosidase assay}

$\alpha$-Glucosidase activity was assayed by measuring the release of $p$-nitrophenol from the substrate $\mathrm{p}$-nitrophenyl- $\alpha$-D-glucoside ( $\mathrm{p}$ $\mathrm{NPG})$. An assay mixture $(0.25 \mathrm{ml})$ consisting of a $0.1 \mathrm{M}$ phosphate-potassium ( $\mathrm{pH}$ 7.0), 15 $\mathrm{mM}$ of $\mathrm{p}-\mathrm{NPG}$ and enzyme solution. After incubation for $20 \mathrm{~min}$ at $40{ }^{\circ} \mathrm{C}$, the reaction was stopped by the addition of $\mathrm{Na}_{2} \mathrm{CO}_{3}$ at a concentration of $0.1 \mathrm{M}$, and absorbance of the reaction mixture was measured at $410 \mathrm{~nm}$. One unit of the enzyme activity was defined as the amount of enzyme liberating $1 \mu \mathrm{mol}$ of $\mathrm{p}$ nitrophenol per minute.

\section{Effect of physicochimicals parameters on $\alpha$ - Glucosidase production}

\section{Effect of incubation time}

The effect of incubation time on enzyme production was investigated by checking the enzyme activity on $0 \mathrm{~h}, 24 \mathrm{~h}, 48 \mathrm{~h}, 72 \mathrm{~h}$ and $96 \mathrm{~h}$ of incubation of fermentation media $(\mathrm{pH}$ 7) in orbital shaker (Shaking incubator, Biobase) at $30{ }^{\circ} \mathrm{C}$ set in 150 rpm. $\alpha$ glucosidase activity was assayed by measuring the release of $p$-nitrophenol from the substrate p-nitrophenyl- $\alpha$-D-glucoside (p-NPG).

\section{Effect of incubation temperature}

The effect of incubation temperature on enzyme production was investigated by fermentation in different substrates and incubated at $28{ }^{\circ} \mathrm{C}, 30{ }^{\circ} \mathrm{C}, 37^{\circ} \mathrm{C}$ and $40{ }^{\circ} \mathrm{C}$ at pH 7 in orbital shaker (shaking incubator, Biobase) set in $150 \mathrm{rpm}$ for 48 hours. $\alpha$ glucosidase activity was assayed by measuring the release of p-nitrophenol from the substrate p-nitrophenyl- $\alpha$-D-glucoside (p-NPG).

\section{Effect of medium pH}

The effect of $\mathrm{pH}$ on enzyme production was investigated by adjusting the $\mathrm{pH}$ of differents fermentation media to $4,5,6,7,8,9$ and 10 . The media were incubated at $30{ }^{\circ} \mathrm{C}$ in orbital shaker (shaking incubator, Biobase) set in 150 rpm for 48 hours. $\alpha$-glucosidase activity was assayed by measuring the release of $p$ nitrophenol from the substrate p-nitrophenyl$\alpha$-D-glucoside (p-NPG).

\section{Effect of agitation speed}

The effect of agitation speed was investigated by incubating a differents media at $0 \mathrm{rpm}, 50$ $\mathrm{rpm}, 100 \mathrm{rpm}, 150 \mathrm{rpm}$ and $180 \mathrm{rpm}$ in orbital shaker (shaking incubator, Biobase) at $30{ }^{\circ} \mathrm{C}$ for 48 hours. $\alpha$-glucosidase activity was assayed by measuring the release of $p$ nitrophenol from the substrate p-nitrophenyl$\alpha$-D-glucoside ( $\mathrm{p}-\mathrm{NPG}$ ).

\section{Statistical assay}

The results obtained during this study were the subject of a statistical processing with software $\mathrm{R}$ version 3.2.2. The averages obtained from three values were compared by variance analysis (ANOVA), then by Turkey test with level of significance $5 \%$.

\section{Results and Discussion}

\section{Effect of time incubation on $\alpha$-glucosidase production}

The enzymatic activities obtained during the fermentation carried out with 12 hours of preculture are recorded in the table 1. All enzymatic activities are increased to the beginning until the 48th hour of fermentation. The maximum activities were respectively to $5.592 \pm 0.18 \mathrm{U} / \mathrm{mL}, 3.00 \pm 0.146 \mathrm{U} / \mathrm{mL}, 9.147$ $\pm 0.098 \mathrm{U} / \mathrm{mL}$ and $4.334 \pm 0.22 \mathrm{U} / \mathrm{mL}$ for $S$. cerevisiae $\mathrm{C} 8-5, \quad C$. tropicalis $\mathrm{C} 0-7$, the 
cocultures (1:1) and (2:1) in medium formulated by $1 \%$ of corn starch. In medium formulated by $1 \%$ of millet starch, important activities were obtained by a pure culture of $S$. cerevisiae C8-5 after 48 hours of fermentation. The activity value was $6.37 \pm$ $0.53 \mathrm{U} / \mathrm{mL}$. The cocultures $(1: 1)$ and $(2: 1)$ are enregistred their important activities at 72 hours of fermentation with a respective values of $4.88 \pm 0.34 \mathrm{U} / \mathrm{mL}$ and $4.75 \pm 0.54$ U/mL.After 48 hours, all activities are dicreased.Overall, $\mathrm{pH}$ values experienced slight acidification during the first 24 hours before becoming basic for the rest of fermentation.

The most important activities were obtained in a $\mathrm{pH}$ range between 6.75 and 7.2 , whether its corn starch or millet starch that is used as a carbon source. This observation is similar than Muhammad et al., (2014) and Muhammad et al., (2016) studies. These authors obtained $\alpha$ glucosidase activity from Bacillus licheniformis KIBGE-IB4 at $\mathrm{pH} 7$ using medium with a sweet potato skin and a synthetic medium respectively. This slight acidification could be due to the organic acids synthesis during fermentation by the strains used. The most important $\alpha$-glucosidase activities for cultures observed at 48 hours of fermentation has an interesting industrial aspect in terms of production time, especially for pure cultures of $S$. cerevisiae 8-5 and $C$. tropicalis $\mathrm{C} 0-7$, unlike other fungal strains that produced enzymes after 120 hours of fermentation (Gianesi et al., 2006). However, it should be noted that the optimum time of fermentation varies from one microbial species to another for the production of enzymes. Thus the maximum production of xylanase by Geobacillus stearothermophilus KIBGE-IB29 was postponed to 24 hours of fermentation while Aspergillus hortai showed maximum productivity of endo-1,4- $\beta$-Dglucanase after 96 hours of fermentation (Bibi et al., 2014; El-Hadi et al., 2014).The study of
Ackan et al., (2011) also showed that the production of $\alpha$-amylase by Bacillus subtilis RSKK96 required 72 hours of fermentation. In the case of our study, after 48 hours of incubation for all cultures, the $\alpha$-glucosidic activity decreases. This decrease could be attributed to the alteration of the medium $\mathrm{pH}$, the scarcity of nutrients or the synthesis of inhibitory metabolites (Pérvez et al., 2015).

\section{Effect of incubation temperature on $\alpha$ - glucosidase production}

The influence of incubation temperature on $\alpha$ glucosidase activity of the different cultures of the strains is presented in Figure 1. The different activities increase with the increase of incubation temperature. All cultures recorded their highest activity at $37^{\circ} \mathrm{C}$ and were respectively $5.67 \mathrm{U} / \mathrm{mL}, 3.75 \mathrm{U} / \mathrm{mL}$, $3.85 \mathrm{U} / \mathrm{mL}$ and $3.14 \mathrm{U} / \mathrm{mL}$ for $S$. cerevisiae C8- 5, C. tropicalis C0-7, cocultures (1:1) and (2:1) in medium formulated with $1 \%$ of millet starch (Fig. 1B). In production medium containing $1 \%$ of corn starch, the most important activities were recorded with the pure cultures of $S$. cerevisiae $\mathrm{C} 8-5$ and $C$. tropicalis $\mathrm{C} 0-7$ with respective activity values of $10.924 \mathrm{U} / \mathrm{mL}$ and $8.148 \mathrm{U} / \mathrm{mL}$ (Fig. 1A) at $37{ }^{\circ} \mathrm{C}$. Above this temperature $\left(37^{\circ} \mathrm{C}\right)$, all activities recorded a slight decrease in their values. Overall, the pure cultures of the strains yielded the largest activities compared to cocultures.

Incubation temperature is one of the most important environmental factors that directly affects the growth of microbial cells and the synthesis of different biomolecules by controlling the physiological activities and microorganisms metabolism (Irfan et al., 2014; Garciaa et al., 2015). The incubation temperature still plays a key role in the production and stability of the enzymes. Of the two environment types, the best activities were obtained with pure cultures at $37{ }^{\circ} \mathrm{C}$. 
Since the strains used for the enzyme production are a mesophilic nature, they are capable to produce $\alpha$-glucosidase at $37^{\circ} \mathrm{C}$. The optimum temperature for microbial growth usually varies from one microorganism to another and depends on mesophilic or thermophilic nature of microorganism (Kumar and Takagi, 1999).A similar result was observed with the use of Bacillus licheniformis KIBGE-IK4 for maximum production of maltase at $37{ }^{\circ} \mathrm{C}$ (Muhammad et al., 2014). The decrease of $\alpha$ glucosidase activity observed above $37{ }^{\circ} \mathrm{C}$ could be justified by the fact that high temperatures would improve the metabolic activity of microbial cells by increasing the kinetic energy of biomolecules. After reaching a certain level of speed, these biomolecules will begin to denature and cause slowing or stopping of microbial cell growth as well as the production of enzyme. Decreasing of $\alpha$ glucosidase activity above $37^{\circ} \mathrm{C}$ could also be justified simply because at high temperature, enzyme production could be negatively affected because of the thermal denaturation of the enzyme.

Increasing of temperature beyond the optimal temperature may also alter the structure of the cell membrane and thereby stimulate protein catabolism, ultimately causing cell death (Amin et al., 2014). Thus, authors such as Pandey et al., (2000) and Vidyalakshmi et al., (2009) meant that high temperatures slowed the growth of bacteria and thus inhibited enzyme production. Our results are similar to those obtained by Karim et al., (2015) who, after studying the production of endo-1,4- $\beta$-Dglucanase by Bacillus licheniformis KIBGEIB2, found that activity above $37{ }^{\circ} \mathrm{C}$ had decreased. Indeed, higher temperatures $(>40$ ${ }^{\circ} \mathrm{C}$ ) and a large variation in physiological $\mathrm{pH}$ lead to denaturation of enzymes, which limits the use of these macromolecules in nonphysiological conditions (Rajendra et al., 2016. However, some authors have showed in their studies that $\alpha$-glucosidase activity can be achieved at incubation temperatures above 37 ${ }^{\circ} \mathrm{C}$. This is the case of Pant et al., (2015) and Muhammad et al., (2016) who obtained maximal protease and $\alpha$-glucosidase activities from Bacillus subtilis and Bacillus licheniformis KIBGE-IK4 respectively at 45 ${ }^{\circ} \mathrm{C}$ and $40{ }^{\circ} \mathrm{C}$. Our study also revealed that all crops recorded the lowest value of their activities at lowest incubation temperature (28 $\left.{ }^{\circ} \mathrm{C}\right)$. Indeed, the temperature below the optimal microbial growth temperature would be a limiting factor of the facilitated transport of nutrients and the exchange of products between the intracellular medium and the extracellular medium. Low temperatures would significantly decrease both the permeability of the cell membrane and the rate of metabolic reactions (Rajoka et al., 2006).

This result is different from that recorded in other studies that have mentioned optimal production temperatures of the enzyme close to $37^{\circ} \mathrm{C}$. This is the case of the production of $\alpha$-amylase by Bacillus subtilis and Bacillus sp at $35{ }^{\circ} \mathrm{C}$ (Krishna and Chandrasekaran, 1996; Vidyalakshmi et al., 2009).

\section{Effect of medium pH on $\alpha$-glucosidase production}

The effect of the $\mathrm{pH}$ of fermentation medium on $\alpha$-glucosidase production is showed in Figure 2. Thus the activities of the strain cultures increase from $\mathrm{pH} 4$ to $\mathrm{pH} 6$ to reach their maximum at $\mathrm{pH} 7$. These maximums are $6.587 \mathrm{U} / \mathrm{mL}, 4.903 \mathrm{U} / \mathrm{mL}, 4.075 \mathrm{U} / \mathrm{mL}$ and $3.875 \mathrm{U} / \mathrm{mL}$ respectively for $S$. cerevisiae $\mathrm{C} 8$ 5 , C. tropicalis $\mathrm{C} 0-7$, cocultures $(1: 1)$ and (2:1) in medium formulated with $1 \%$ of millet starch (Fig. 2A). In medium containing $1 \%$ of corn starch, the important activities were obtained at $\mathrm{pH} 7$ and are respectively 9.764 $\mathrm{U} / \mathrm{mL}, 5.835 \mathrm{U} / \mathrm{mL}, 4.578 \mathrm{U} / \mathrm{mL}$ and 4.352 $\mathrm{U} / \mathrm{mL}$ for $S$. cerevisiae C8-5, C. tropicalis $\mathrm{C} 0-$ 7, cocultures (1:1) and (2:1) (Fig. 2B). 
Fig.1 Effect of incubation temperature on $\alpha$-glucosidase production (A: $1 \%$ of corn starch; B: $1 \%$ of millet starch)
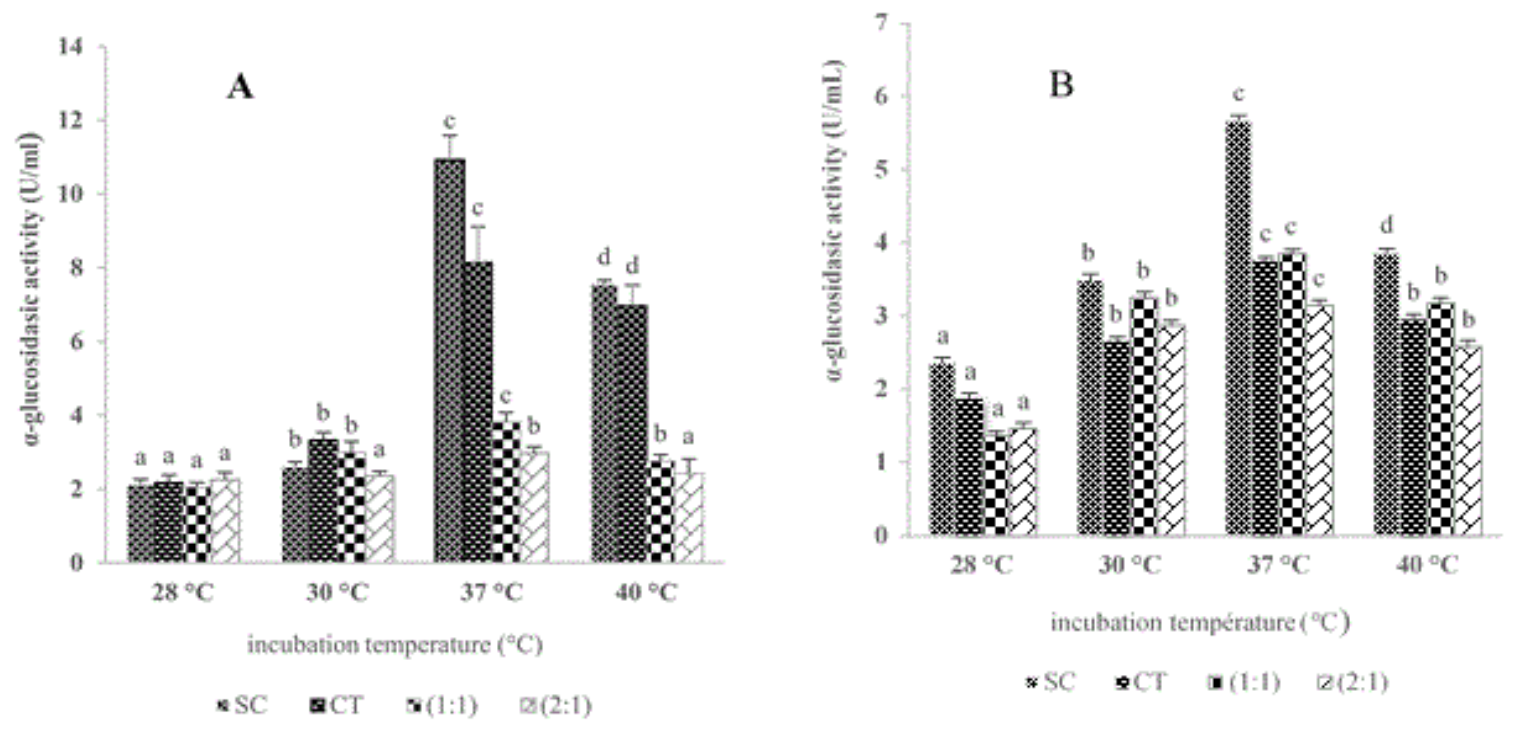

NB: The bonds of same colour carrying the same letters do not present a significant difference to the level of 5\%

Fig.2 Effect of fermentation medium $\mathrm{pH}$ on $\alpha$-glucosidase production (A: $1 \%$ of millet starch; B: $1 \%$ of corn starch)
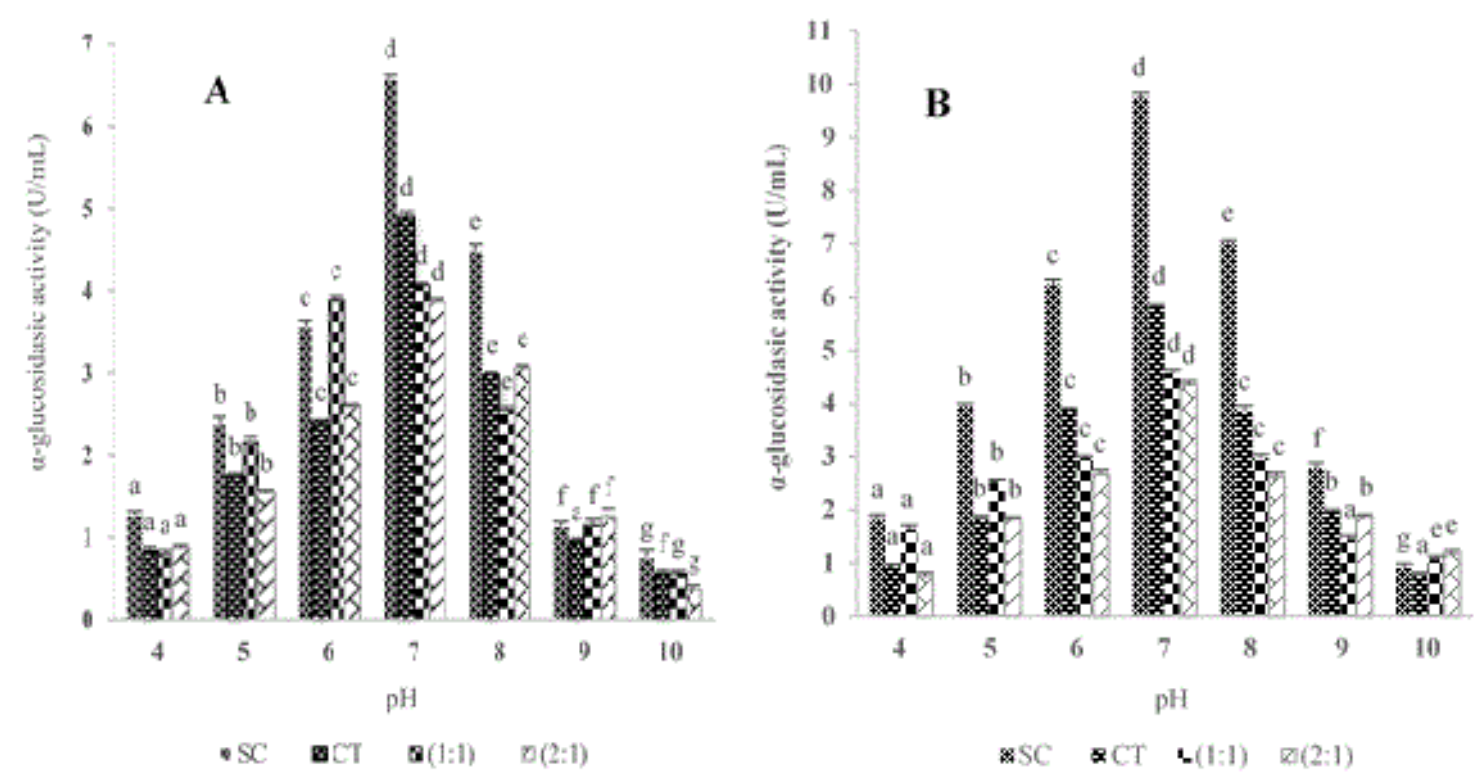

NB: The bonds of same colour carrying the same letters do not present a significant difference to the level of 5\% 
Fig.3 Effect of agitation speed on $\alpha$-glucosidase production (A: 1\% of corn starch; B: 1\% of millet starch)
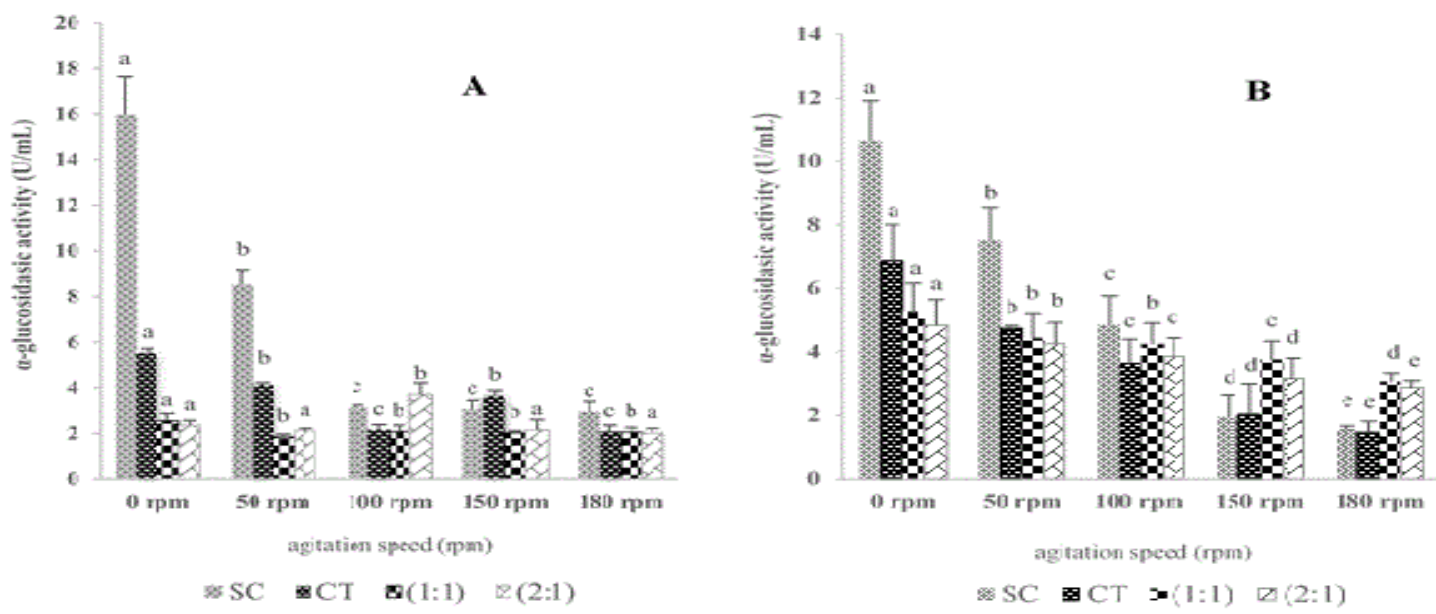

NB: The bonds of same colour carrying the same letters do not present a significant difference to the level of 5\%

Table.1 Effect of time incubation on $\alpha$-glucosidase production (A: $1 \%$ of millet starch; B: $1 \%$ of corn starch $1 \%$ )

\begin{tabular}{|c|c|c|c|c|c|c|}
\hline \multirow[t]{2}{*}{1} & & \multicolumn{5}{|c|}{ Fermentation time (Hour) } \\
\hline & & $\mathbf{0}$ & 24 & 48 & 72 & 96 \\
\hline \multirow[b]{2}{*}{ SC } & Enzyme activity (U/mL) & $0 \pm 0^{a}$ & $3.64 \pm 0.65^{\mathbf{b}}$ & $6.37 \pm 0.53^{c}$ & $4.56 \pm 0.45^{d}$ & $3.75 \pm 0.087^{\mathbf{b}}$ \\
\hline & pH & $7 \pm 0$ & $6.62 \pm 1.05$ & $6.94 \pm 0.97$ & $7.14 \pm 1.02$ & $7.47 \pm 0.89$ \\
\hline \multirow[b]{2}{*}{ CT } & Enzyme activity (U/mL) & $0 \pm 0^{a}$ & $3.45 \pm 0.76^{\mathbf{b}}$ & $4.84 \pm 0.87^{\mathrm{c}}$ & $4.27 \pm 0.57^{\mathrm{d}}$ & $3.55 \pm 0.35^{\mathbf{b}}$ \\
\hline & $\mathbf{p H}$ & $7 \pm 0$ & $6.53 \pm 0.78$ & $6.76 \pm 0.89$ & $6.98 \pm 0.98$ & $7.23 \pm 0.75$ \\
\hline \multirow[b]{2}{*}{$(1: 1)$} & Enzyme activity (U/mL) & $0 \pm 0^{a}$ & $3.38 \pm 0.336^{\mathbf{b}}$ & $4.12 \pm 0.65^{\mathrm{c}}$ & $4.88 \pm 0.34^{d}$ & $3.78 \pm 0.27^{\mathrm{e}}$ \\
\hline & $\mathbf{p H}$ & $7 \pm 0$ & $6.48 \pm 0.63$ & $6.71 \pm 0.75$ & $7.05 \pm 0.88$ & $7.23 \pm 1.12$ \\
\hline \multirow[b]{2}{*}{$(2: 1)$} & Enzyme activity (U/mL) & $0 \pm 0^{\mathrm{a}}$ & $3.33 \pm 0.47^{\mathbf{b}}$ & $3.89 \pm 0.43^{\mathrm{c}}$ & $4.75 \pm 0.54^{\mathrm{d}}$ & $3.67 \pm 0.58^{\mathrm{c}}$ \\
\hline & pH & $7 \pm 0$ & $6.56 \pm 0.95$ & $6.86 \pm 0.87$ & $7.12 \pm 0.67$ & $7.48 \pm 0.88$ \\
\hline
\end{tabular}

\begin{tabular}{|c|c|c|c|c|c|c|}
\hline & & \multicolumn{5}{|c|}{ Fermentation time (Hour) } \\
\hline & & $\mathbf{0}$ & 24 & 48 & 72 & 96 \\
\hline \multirow[t]{2}{*}{$\mathrm{SC}$} & Enzyme activity (U/mL) & $0 \pm 0^{\mathrm{a}}$ & $2.17 \pm 0.21^{\mathbf{b}}$ & $5.59 \pm 0.18^{\mathbf{c}}$ & $3.655 \pm 0,58^{\mathrm{d}}$ & $3.417 \pm 0.32^{\mathrm{d}}$ \\
\hline & pH & $7 \pm 0$ & $6.7 \pm 0.05$ & $6.83 \pm 0.02$ & $7.45 \pm 0,065$ & $7.87 \pm 0.035$ \\
\hline \multirow[t]{2}{*}{$\mathrm{CT}$} & Enzyme activity (U/mL) & $0 \pm 0^{\mathbf{a}}$ & $2.27 \pm 0.232^{b}$ & $3 \pm 0.146^{c}$ & $2.057 \pm 0.3^{\mathbf{b}}$ & $1.757 \pm 0.18^{d}$ \\
\hline & pH & $7 \pm 0$ & $6.85 \pm 0.015$ & $6.95 \pm 0.03$ & $7.23 \pm 0.025$ & $7.64 \pm 0.035$ \\
\hline \multirow[t]{2}{*}{$(1: 1)$} & Enzyme activity (U/mL) & $0 \pm 0^{\mathrm{a}}$ & $2.436 \pm 0.24^{b}$ & $9.14 \pm 0.098^{\mathrm{c}}$ & $2.71 \pm 0.31^{\mathrm{d}}$ & $2.037 \pm 0.07^{\mathrm{e}}$ \\
\hline & pH & $7 \pm 0$ & $6.64 \pm 0.0208$ & $6.76 \pm 0.015$ & $7.03 \pm 0.015$ & $7.26 \pm 0.015$ \\
\hline \multirow[t]{2}{*}{$(2: 1)$} & Enzyme activity (U/mL) & $0 \pm 0^{\mathbf{a}}$ & $3.35 \pm 0.75^{\mathbf{b}}$ & $4,33 \pm 0.22^{\mathbf{c}}$ & $3.5 \pm 0.16^{\mathbf{b}}$ & $2.137 \pm 0.248^{\mathrm{d}}$ \\
\hline & pH & $7 \pm 0$ & $6.55 \pm 0.025$ & $6.86 \pm 0.032$ & $7.12 \pm 0.025$ & $7.55 \pm 0.025$ \\
\hline
\end{tabular}

NB: On the same line, the values carrying the same letters do not present a significant difference to the level of $5 \%$ 
A pure culture favorised more production of $\alpha$-glucosidase compared to cocultures and the most important activities were obtained with S. cerevisiae C8-5. Beyond $\mathrm{pH} 7$, strain cultures are experiencing a gradual decline in activity and this decrease is accentuated between $\mathrm{pH} 9$ and 10 where all activity values are less than $1 \mathrm{U} / \mathrm{mL}$.

Among the parameters influencing enzyme production, $\mathrm{pH}$ is also a very important chemical factor affecting microbial growth and metabolite production (Banargee and Bhattacharya, 1992). In fact, the growth of microorganisms as well as the progress of many enzymatic reactions, are strongly influenced by the $\mathrm{pH}$ which in turn influences the enzymatic structure and the ions transport, metabolites and enzymes across the cell membrane (Liang et al., 2010). The results of our study showed that the production of $\alpha$ glucosidase was better ensured when fermentation media were brought to $\mathrm{pH} \mathrm{7,}$ regardless of the carbon source used. Most bacterial and fungal strains can be grown at $\mathrm{pH}$ 6.0-7.0 for growth and enzyme production (Castro et al., 1992; Gupta et al., 2003). Optimum $\mathrm{pH}$ played an important role in the enzyme production because it can either lower the production of the enzyme by inhibiting the growth of the microorganism, or by creating an inadequate toxic environment that leads to denaturation or inactivation of the enzyme produced (Bajaj and Abbass, 2011). During the production of enzymes, microorganism were generally confronted at two different $\mathrm{pH}$ that are the $\mathrm{pH}$ of culture medium or external $\mathrm{pH}$ and the intracellular $\mathrm{pH}$ or internal $\mathrm{pH}$. In the majority of microorganisms, the internal $\mathrm{pH}$ value is close to neutral $\mathrm{pH}$. Thus the production of $\alpha$-glucosidase recorded in our study would be facilitated by the dependence between the two types of $\mathrm{pH}$. Indeed, the molecules are transported towards inside of cell under the influence of external $\mathrm{pH}$. Once inside the cell, these molecules are used by the internal $\mathrm{pH}$ for protein production, enzymatic activities and excretion of metabolites during fermentation (Liu et al., 2003). Thus extreme $\mathrm{pH}$ values could damage the cell membrane and thus cause cell death (Liu et al., 2003). The production of enzymes with near-neutral $\mathrm{pH}$ has been mentioned in several studies. This is the case of carboxymethylcellulase (CMcase) and of the alkaline protease produced respectively by Aspergillus hortai and Bacillus sp in liquid fermentation medium at an optimum $\mathrm{pH}$ to 7 (El-Hadi et al., 2014; Ibrahim et al., 2015). However, any change in medium $\mathrm{pH}$ may influence the ionization state of various nutritionally important components and may also reduce their availability to microbial cells. This $\mathrm{pH}$ change could lead to the accumulation of toxic fermentation products, which would inhibit a multiplication of microbial cells responsible to enzymes secretion. Indeed enzymes reach their maximum activities at their different optimal conditions and therefore, would be inhibited by any fluctuation of these conditions (Bisswanger, 2014). At optimum $\mathrm{pH}$, the catalytic site of enzyme is at ionization level. For this reason any change in the optimal incubation temperature could affect the integrity of secondary, tertiary and quaternary structure of the enzyme which, in turn would affect enzymatic activity (Meryandini et al., 2006).

\section{Effect of agitation speed on $\alpha$-glucosidase production}

The study of the effect of agitation speed on the production of $\alpha$-glucosidase is shown in Figure 3. The $\alpha$-glucosidase activity decreased with the increasing of agitation speed. Thus the most important activities were obtained when the fermentation media are not subjected to agitation (0 rpm). In medium containing $1 \%$ of corn starch (Fig. 3 
A), S. cerevisiae C8-5 recorded the highest activity at $15.96 \mathrm{U} / \mathrm{mL}$ followed by $C$. tropicalis $\mathrm{C} 0-7$ at $5.532 \mathrm{U} / \mathrm{mL}$.

In medium formulated with $1 \%$ of millet starch, the important activities are obtained from pure cultures in particular, that of $S$. cerevisiae C8-5 with an activity of 10.657 $\mathrm{U} / \mathrm{mL}$. As for cocultures, the best activities are obtained with coculture (1: 1) and are between $6.854 \mathrm{U} / \mathrm{mL}$ and $3.063 \mathrm{U} / \mathrm{mL}$ respectively at $0 \mathrm{rpm}$ and $180 \mathrm{rpm}$ (Fig. 3B). Overall, fermentations from pures cultures of $S$. cerevisiae $\mathrm{C} 8-5$ and $C$. tropicalis $\mathrm{C} 0-7$ resulted in significantly higher $\alpha$-glucosidase activities than those obtained from media formulated with cocultures (1:1) and (2: 1).

To achieve a good fermentation in a liquid medium, agitation is one of the most important parameters that influenced the production of enzymes. According to Jang and Chang (2005), agitation affects oxygen mass transfer and would be a crucial factor for enzyme production during fermentation. The results of our study are revelated that $\alpha$ glucosidase production was greater in the media subjected to an agitation speed of 0 rpm and with the pure cultures of the strains. In fact, the uniform distribution of nutrients and the oxygen demand satisfaction during the fermentation are under the control of the agitation speed (Andhyaru et al., 2014). These results could be explained by the fact that high agitation rates would have a negative impact on cell growth and thus on enzyme production (Xia et al., 2014). This remark explains the low activity values obtained in our work when were subjected to higher agitation speeds (> $100 \mathrm{rpm}$ ).

Indeed, the fermentation was carried out in Erlenmeyer flasks of $250 \mathrm{ml}$ capacity with 50 $\mathrm{ml}$ in order to have a volume of oxygen corresponding to quarter of total volume of Erlenmeyer flask. Thus during fermentation, the agitation speed would favor a uniform distribution of the oxygen mass given the aerobic nature of the strains. This oxygen mass which, subjected to a high speed of agitation would be quickly exhausted and, consequently, would put the strains in a state of stress. The latter would produce other metabolites that either inhibit the enzyme production or would be inactive for its production. In contrast to media subjected to low agitation speeds, the oxygen quantity would be less quickly exhausted and facilitate the production of the desired enzyme. This observation was made by Asisipho et al., (2017) during the cellulase and xylanase production by Bacillus species. These authors mentioned that beyond $100 \mathrm{rpm}$ the production of xylanase was negatively affected.

The study allowed us to quantify the amylolytic and especially $\alpha$-glucosidase activities of $S$. cerevisiae $\mathrm{C} 8-5$ and $C$. tropicalis $\mathrm{C} 0-7$ strains. The results obtained revealed that the use of a 12 hours preculture made it possible to obtain the most important enzymatic activities in this work. After 48 hours of fermentation, all strain cultures had reached their maximum activity. S. cerevisiae C8-5 was the most prolific strain for $\alpha$ glucosidase production. The medium enriched with $1 \%$ corn starch favorized the production of this enzyme with a pure culture of $S$. cerevisiae $\mathrm{C} 8-5$. The optimization of the parametres of $\alpha$-glucosidase production was concerned the variation of fermentation time, $\mathrm{pH}$ of fermentation medium, agitation speed and the incubation temperature. The study of these parameters has revelated that $\alpha$ glucosidase production was maximum at 48 hours of fermentation, at $\mathrm{pH} \mathrm{7}$, at temperature of $37{ }^{\circ} \mathrm{C}$ and without agitation of fermentation medium $(0 \mathrm{rpm})$. Thus, our strains are produced amylolytic activity and particularly $\alpha$-glucosidase activity which has been greater with a pure culture of $S$. cerevisiae $\mathrm{C} 8-5$. The 
corn starch and millet starch could be used as carbon source for $\alpha$-glucosidase production. That would reduce the synthetic starch dependence and could constituite a veritable substrate for industrial production of enzyme.

\section{References}

Abu, E.A., Ado, S.A., and James, D.B. 2005. Raw starch degrading amylase production by mixed culture of Aspergillus niger and Saccharomyces cerevisae grown on sorghum pomace. African Journal of Biotechnology, 4 (8): 785-790

Ackan, N., Uyar, F., and Güven, A. 2011. Alpha amylase production by Bacillus subtilis RSKK96 in Submerged Cultivation. Kafkas University, DOI:10.9775/kvfd.2010.3036

Adewara, A.O., and Ogunbanwo, S.T. 2013. Effects of processing variables on the production of "Burukutu", a Nigerian fermented beverage. Nature Sciences, 11: $16-28$

Alloue-Boraud, W.A.M., N'Guessan, K.F., Djeni, N.T., Hiligsmann, S., Djè, K.M., and Delvigne, F., (2014). Fermentation profile of Saccharomyces cerevisiae and Candida tropicalis as starter cultures on barley malt medium. Journal of Food Science and Technology, $9 \mathrm{p}$.

Amin, M., Bhatti, H.N., Zuber, M., Bhatti, I.A., and Asgher M. 2014. Potential use of agricultural wastes for the production of lipase by Aspergillus melleus under solid state fermentation. Journal of Animal and Plant Sciences, 23:14301437

Asisipho, N., Kunle, O., Ademola, O., Uchechukwu, N., Mabinya, L., and Okoh, A. 2017. Optimization of growth parameters for cellulase and xylanase production by Bacillus species isolated from decaying biomass. Journal of Biotechnology Research, 8: 33-47
Bajaj, B.K., and Abbass, M. 2011. Studies on an alkali-thermostable xylanase from Aspergillus fumigatus MA28. 3 Biotechnology, 1:161-171.

Banargee, R., and Bhattacharya, B.C. 1992. Extra cellular alkaline protease of newly isolated Rhizopus oryzae. Biotechnology Letters, 14: 301-304

Bisswanger, H. 2014. Enzyme assays. Perspectives Sciences, 1: 41-55

Bouatenin, K.M.J-P., Djeni, N.T., Kakou, A.C., Menan, E.H., and Dje K.M. 2016. Optimisation de la production de l' $\alpha$ amylase par les microorganisms isoles des ferments traditionnels de manioc provenant de trois zones de production de l'attieké en Côte d'Ivoire. European Scientific Journal, 12(9): 259-272

Choi, J.M., Han, S.S., and Kim, H.S. 2015. Industrial applications of enzyme biocatalysis: current status and future aspect. Biotechnology Advances, 33:1443-1454

El-Hadi, A., El-Nour, S.A., Hammad, A., Kamel, Z., and Anwar, M. 2014. Optimization of cultural and nutritional conditions for carboxymethylcellulase production by Aspergillus hortai. Journal of Radiation and Research Applied Sciences, 7: 23-28

Ellis, J.T., and Magnuson, T.S., (2012). Thermostable and alkalistable xylanases produced by the thermophilic bacterium Anoxybacillus flavithermus TWXYL3. ISRN Microbiology, doi: 10.5402/2012/517524

Garciaa, N.F.L., Santosa, F.R., Gonçalvesb, F.A., Paza, M.F., Fonsecab, G.G., Leitea, R.S.R. 2015. Production of $\beta$ glucosidase on solid-state fermentation by Lichtheimia ramosa in agroindustrial residues: characterization and catalytic properties of the enzymatic extract. Electronic Journal of Biotechnology, 18: 314-319 
García-Martínez, A.M., Díaz, A., Tejada, M., Bautista, J., Rodríguez, B., Santa-María, C., Revilla, E., and Parrado, J. 2010. Enzymatic production of an organic soil biostimulant from wheat-condensed distiller solubles: Effects on soil biochemistry and biodiversity. Process Biochemistry, 45(7): 1127-1133

Gianesi, G.C., Polizeli, M.D.L.T.D.M., Terenzi, H.F., and Jorge J.A. 2006. A novel $\alpha$ - glucosidase fromChaetomium thermophilium var. coprophilium that converts maltose into trehalose: Purification and partial characterization of the enzyme. Process Biochemistry, 41: 1729-1735

Glover, R.L.K. et al., 2009. Utilization of Lactobacillus fermentum and Saccharomyces cerevisiae as starter cultures in the production of "dolo". Journal of Applied Biosciences, 22: 1312-1319

Gupta, A.K., and Gautam, S.P. 1993. Purification and properties of an extracellular a-glucosidase from thethermophilic fungus Malbranchea sulfurea. Journal of General Microbiology, 139: 963-967

Gupta, R., Gigras, P., Mohapatra, H., Goswami, V.K., and Chauhan, B. 2003. Microbial $\alpha$-amylases:

a biotechnological perspective. Processes Biochemistry, 38(11): 1599-1616

Holzapfel, W.H. 2002. Appropriate starter culture technology for small-calle fermentation in developing countries. International Journal of Food and Microbiology, 75: 197-212

Ibrahim, A.S.S., Al-Salamah, A.A., Elbadawi, Y.B., El-Tayeb, M.A., and Ibrahim, S.S.S. 2015. Production of extracellular alkaline protease by new halotolerant alkaliphilic Bacillus sp. NPST-AK15 isolated from hyper saline soda lakes. Electron Journal of Biotechnology, 18: 236-243
Irfan, M., Nadeem, M., and Syed, Q. 2014. One-factor at-a-time (OFAT) optimization of xylanase production from Trichoderma viride-IR05 in solidstate fermentation. Journal of Radiation and Research Applied Sciences, 7: 317326

Jang, H.D., and Chang, K.S. 2005. Thermostable cellulases from Streptomycessp.: Scale-up production in a 501 fermenter. Biotechnology Letters, 27: 239-242

Karim, A., Nawaz, M.A., Aman, A., Qader, S.A.U., 2015. Hyperproduction of cellulose degrading endo $(1,4) \quad \beta$-Dglucanase from Bacillus licheniformis KIBGE-IB2. Journal of Radiation and Research Applied Sciences, 8: 160-165

Krishna, C., and Chandrasekaran, M. 1996. Banana waste as substrate for -amylase production byBacillus subtilis (CBTK106) under solid state fermentation. Applied of. Microbiology and Biotechnology, 46: 106-111

Kumar, C.G., and Takagi, H. 1999. Microbial alkaline proteases: from a bioindustrial viewpoint.Biotechnology Advances, 17: 561-594

Li, S., Yang, X., and Yang S. 2012. Technology prospecting on enzymes: application, marketing and engineering. Comput Struct Biotechnol Journal, 2: 111

Liang, Y., Feng, Z., Yesuf, J., and Blackburn, J.W. 2010. Optimization of growth medium and enzyme assay conditions for crude cellulases produced by a novel thermophilic and cellulolytic bacterium, Anoxybacillus sp. 527. Applied of Biochemistry and Biotechnology, 160: 1841-1852

Liu, S., Lin, C., Xie L., and Cao, Z. 2003. Intracellular $\mathrm{pH}$ and metabolic activity of long-chain dicarboxylic acid producing yeast Candida tropicalis. 
Journal of Biosciences and Bioengineering, 96(4): 349-353

Maktouf, S. 2013. Activités amylase et lichenase d'une nouvelle souche de Bacillus. Production sur milieu solide et caractérisation. Thèse de Doctorat de l'Université de Toulouse, $138 \mathrm{p}$

Marin, D., Linde, D., and Lobato, M.F.2006. Purification and biochemical characterization of an $\alpha$-glucosidase from Xanthophyllomyces dendrorhous.Yeast, 23: 117-125

Meryandini, A., Hendarwin, T., Saprudin, D., and Lestari Y. 2006. Characterization of XylanaseStreptomyces spp. SKK1-8. HAYATI Journal of Biosciences, 13: 151-155

Muhammad, A.N., Bibi, Z.N., Ansari, A., Zohra, R.R., and UI-Qader, S.A. 2014. Enhanced production of maltase $(\alpha$ glucosidase) from newly isolated strain of Bacillus licheniformis KIBGE-IB4. Pakistan Journal of Pharmaceutical Sciences, 27(5): 1437-1442

Muhammad, A.N., Bibi, Z.N., Asad, K., Haneef, U.R., Muhsin, J., Tour, J., Afsheen, A., and Qader, U.S.A. 2016. Production of $\alpha$-1,4-glucosidase from Bacillus licheniformis KIBGE-IB4 by utilizing sweet potato peel. Environnement Science of Pollution Research, DOI 10.1007/s11356-0168168-x

N'guessan, F.K., Brou, K., Noémie, J., Casaregola, S., and Djè, K.M. 2011. Identification of yeasts during alcoholic fermentation of tchapalo, a traditional sorghum beer from Côte d'Ivoire. Antonie van leeuwenhoek, 99(4): 855864

Oliveira, A.P.A., Silvestre, M.A., AlvesPrado, H.F., Rodrigues, A., Da Paz, M.F., Fonseca, G.G., and Leite. 2015. Bioprospecting of yeasts for amylase production in solid state fermentation and evaluation of the catalytic properties of enzymatic extracts. African Journal of Biotechnology, 14(14): 1215-1223

Özdemir, S., Matpan, F., Güven, K., and Baysal, Z. 2014. Production and characterization of partially purified extracellular thermostable $\alpha$-amylase by Bacillus subtilis in submerged fermentation (SmF). Prep. Biochemical and Biotechnology, 41(4): 365-38

Pandey, A., Soccol, C.R., and Mitchell D. 2000. New developments in solid state fermentation. Process Biochemical, 35: 1153-1169

Pant, G., Prakash, A., Pavani, J.V.P., Bera, S., Deviram, G.V.N.S., Kumar, A., Panchpuri, M., and Prasuna, R.G. 2015. Production, optimization and partial purification of protease from Bacillus subtilis.Journal of Taibah University for Science, 9: 50-55

Pervez, S., Siddiqui, N.N., Ansari, A., Aman, A., and UI Qader, S.A. 2015. Phenotypic and molecular characterization of Aspergillus species for the production of starchsaccharifying amyloglucosidase. Annual of Microbiology, 65: 2287-2291

Rajendra, S., Manoj, K., Anshumali, M., and Praveen, K.M. 2016. Microbial enzymes: industrial progress in 21st century. 3 Biotechnology, 6: 174, $15 \mathrm{p}$

Rajoka, M.I., Akhtar, M.W., Hanif, A., and Khalid, A.L. 2006. Production and characterization of a highly active cellobiase from Aspergillus niger grown in solid state fermentation. World Journal of Microbiology and Biotechnology, 22: 991-998

Vidyalakshmi, R., Paranthaman, R., and Indhumathi, J. 2009. Amylase Production on Submerged Fermentation by Bacillusspp. World Journal of Chemistry, 4(1): 89-91

Watcharachaisoponsiri, T., Sornchan, P., Charoenkiatkul, S., and Suttisansanee, 
U. 2016. The $\alpha$-glucosidase and $\alpha$ amylase inhibitory activity from different chili pepper extracts. International Food Research Journal, 23(4): 1439-1445

Xia, X., Lin, S., Xia, X.X., Cong, F.S., and Zhong, J.J. 2014. Significance of agitation-induced shear stress on mycelium morphology and lavendamycin production by engineered Streptomyces flocculus. Applied of Microbiology and Biotechnology, 98: 4399-4407

\section{How to cite this article:}

Yapi Yapi Eric, W.A.M. Alloue-Boraud, Coulibaly W. Hermann and Djè Koffi Marcellin. 2018. Enhanced of $\alpha$-Glucosidase Production by Saccharomyces cerevisiae C8-5 and Candida tropicalis C0-7, Two Yeast Strains Isolated from Tchapalo, a Traditional Sorghum Beer of Côte d'Ivoire. Int.J.Curr.Microbiol.App.Sci. 7(12): 3317-3330.

doi: https://doi.org/10.20546/ijcmas.2018.712.383 